\title{
PENGARUH MODEL PEMBELAJARAN KOOPERATIF TIPE JIGSAW TERHADAP PEMAHAMAN KONSEP IPA SISWA
}

\author{
I.B.P. Angga Putra, N.M. Pujani, P. Prima Juniartina. \\ Program Studi S1 Pendidikan IPA \\ Universitas Pendidikan Ganesha \\ Singaraja, Indonesia
}

e-mail: \{putra.angga,made.pujani,prima.juniartina\}@undiksha.ac.id

\begin{abstract}
Abstrak
Penelitian ini bertujuan untuk mendeskripsikan profil pemahaman konsep IPA siswa dan menganalisis perbedaan pemahaman konsep IPA antara siswa yang belajar dengan model pembelajaran kooperatif tipe Jigsaw dan model pembelajaran langsung. Penelitian ini termasuk penelitian eksperimen semu dengan rancangan Nonequivalent Pretest-Posttest Control Group Design. Populasi dalam penelitian ini adalah seluruh kelas VII SMP N 1 Sukasada pada semester genap tahun ajaran 2017/2018 yang berjumlah 236 siswa. Sampel penelitian dipilih dengan menggunakan teknik class random sampling. Sampel yang digunakan dalam penelitian ini berjumlah 59 siswa yang tersebar dalam 2 kelas, yaitu kelas eksperimen dan kelas kontrol. Data pemahaman konsep diperoleh melalui tes pemahaman konsep IPA. Data yang diperoleh dianalisis secara deskriptif dan Anakova satu jalur. Hasil penelitian menunjukkan bahwa: (1) Pemahaman konsep IPA siswa yang belajar dengan model pembelajaran kooperatif tipe Jigsaw berkualifikasi tinggi $(\mathrm{N}$-gain $=0,74)$. Ketercapaian indikator menafsirkan, mencontohkan, merangkum, menyimpulkan, dan menjelaskan berkualifikasi tinggi. Ketercapaian indikator mengklasifikasikan dan membandingkan berkualifikasi sedang. (2) Terdapat perbedaan pemahaman konsep IPA antara siswa yang belajar dengan model pembelajaran kooperatif tipe Jigsaw dan model pembelajaran langsung $(F=18,063, p<0,05)$. Siswa yang belajar dengan model pembelajaran kooperatif tipe Jigsaw secara signifikan memiliki pemahaman konsep IPA yang lebih tinggi dibandingkan dengan model pembelajaran langsung $\left(\left|\mu_{1}-\mu_{2}\right|>\right.$ LSD). Pada model pembelajaran kooperatif tipe Jigsaw siswa aktif berdiskusi dalam kelompok asal dan kelompok ahli, sehingga memudahkan siswa dalam memahami materi pelajaran.
\end{abstract}

Kata kunci: jigsaw, pembelajaran langsung, pemahaman konsep

\begin{abstract}
This research aimed to describe the students understanding of science concept and analyze the differences in understanding of science concept between students who learn with Jigsaw type cooperative learning model and direct instruction model. This research was a quasi-experimental with nonequivalent pretest-posttest control group design. The population in this research were all students of VII grade of SMP N 1 Sukasada on 2017/2018 academic year, amounting to 236 students. The sample was chosen by using class random sampling technique. The sample used in this research is 59 students spread in 2 classes, that is experiment class and control class. The concept comprehension data is obtained through the comprehension test of the concept of IPA. The data obtained were analyzed descriptively and Anacova one way. The results showed that: (1) Understanding of science concept of students studying with Jigsaw type highly cooperative learning model $(\mathrm{N}$-gain $=0,74)$. Achievement of indicators interpreting, exemplifying, summarising, and explaining highly qualified. Achievement of indicators classifying and comparing moderately qualified. (2) There is difference of understanding of science concept between students studying with Jigsaw type cooperative learning model and direct instruction model $(F=18,063, p<0,05)$. Students learning with Jigsaw type cooperative learning models a significant have a higher understanding of IPA concepts than direct instruction model $\left(\left|\mu_{1}-\mu_{2}\right|>\right.$ LSD). In the cooperative learning model Jigsaw type students actively discuss in groups of origin and expert groups, making it easier for students to understand the subject matter.
\end{abstract}

Keywords: jigsaw, direct instruction, conceptual understanding 


\section{PENDAHULUAN}

Pendidikan merupakan suatu pilar yang sangat penting dalam membangun suatu negara yang berkualitas. Manusia diharapkan tumbuh menjadi individu yang mampu beradaptasi dengan lingkungan sekitar melalui pendidikan. Mutu pendidikan yang tinggi sangat diperlukan untuk mendukung terciptanya sumber manusia yang berkualitas. Pemerintah terus melakukan berbagai upaya untuk meningkatkan kualitas pendidikan. Upayaupaya yang dilakukan antara lain: mengadakan perubahan kurikulum, peningkatan kualitas guru melalui kegiatan sertifikasi, pelatihan profesi guru (PPG), dan pemberian bantuan berupa bantuan operasional sekolah (BOS).

Berbagai upaya yang dilakukan pemerintah seyogyanya dapat memberikan pengaruh yang positif terhadap kualitas pendidikan di Indonesia. Kenyataan yang terjadi di Indonesia ialah kualitas pendidikan belum sesuai dengan harapan. Hal tersebut terlihat dari hasil Program for International Student Assessment (PISA) tahun 2015, Indonesia menduduki peringkat 10 terbawah dari 69 negara yang berpartisipasi, dengan rincian: 1) prestasi literasi membaca siswa Indonesia menduduki peringkat 61 dari 69 negara, 2) prestasi literasi Sains/IPA siswa Indonesia menduduki peringkat 62 dari 69 negara, dan 3) prestasi literasi Matematika siswa ndonesia menduduki peringkat 63 dari 69 negara yang berpartisipasi (Iswadi, 2016). Hal serupa juga terlihat dari hasil Trend in International Mathematics and Science Study (TIMSS) tahun 2015, Indonesia berada pada ranking 36 dari 49 negara yang berpartisipasi (Sarnapi, 2016). Nilai Ujian Nasional (UN) tingkat SMP/Mts di Bali tahun 2017 juga menunjukkan bahwa hasil belajar siswa masih tergolong rendah. Rata-rata nilai Ujian Nasional (UN) tingkat SMP/Mts di Bali tahun 2017 menunjukkan penurunan dari tahun 2016.

Tabel 1. Rata-rata nilai UN tingkat SMP/Mts di Bali

\begin{tabular}{llll}
\hline No & Mata & \multicolumn{2}{l}{ Rata-rata UN } \\
& Pelajaran & $\mathbf{2 0 1 6}$ & $\mathbf{2 0 1 7}$ \\
1 & Bhs Indoneisa & 68,89 & 67,54 \\
2 & Bhs Inggris & 54,22 & 50,40 \\
3 & Matematika & 46,55 & 43,63 \\
4 & IPA & 58,11 & 50,45 \\
\hline
\end{tabular}

Mata pelajaran IPA mengalami penurunan sebesar 13,18\% dari tahun 2016 . Hasil UN tersebut mengindikasikan bahwa rendahnya hasil belajar siswa berkaitan dengan rendahnya pemahaman konsep siswa dalam pembelajaran IPA. Pemahaman konsep memiliki peranan penting dalam proses belajar mengajar dan merupakan dasar dalam mencapai hasil belajar (Widiawati et al., 2015). Rendahnya pemahaman konsep disebabkan karena pembelajaran kurang memperhatikan dari segi proses, sehingga pembelajaran yang terjadi hanya sekedar transfer informasi dari guru ke siswa (Widiadnyana et al., 2014).

Pemahaman konsep menyatakan tingkat penguasaan yang dapat dicapai oleh siswa selama mengikuti proses pembelajaran sesuai dengan tujuan yang telah ditetapkan. Siswa dikatakan
(Disdik Bali, 2017)

memahami konsep apabila mampu mengerti tentang apa yang mereka pelajari dan mengutarakan kembali dengan bahasanya sendiri.

Menurut kurikulum 2013, guru wajib menerapkan pendekatan pembelajaran yang berpusat pada siswa dan menggunakan model pembelajaran yang inovatif dalam pembelajaran di kelas. Realita proses pembelajaran di kelas ialah guru kurang maksimal menerapkan model pembelajaran yang dipilih. Guru cenderung menggunakan model pembelajaran yang masih berpusat pada guru, karena mudah diterapkan dan sudah menjadi kebiasaan guru dalam mengajar di kelas. Proses pembelajaran masih berpusat pada guru dengan memberikan ceramah, tanya jawab, dan pemberian tugas (Oviyana et al., 2015). Proses pembelajaran lebih diarahkan pada 
kemampuan siswa untuk menerima pengetahuan bukan untuk mengkontruksi pengetahuan. Proses pembelajaran hingga dewasa ini masih didominasi guru dan kurang memberikan akses bagi peserta didik untuk berkembang secara mandiri melalui penemuan dalam proses berpikirnya (Surayya et al., 2014). Sebagian besar guru masih cenderung menggunakan model pembelajaran langsung dalam proses pembelajaran. Arends (2013) menyatakan bahwa model pembelajaran langsung adalah model pembelajaran yang bertujuan untuk membantu siswa mempelajari keterampilan dan pengetahuan dasar yang dapat dijabarkan dengan cara bertahap langkah demi langkah.

Secara umum kegiatan dalam model pembalajran langsung terdiri dari 5 tahapan pembelajaran, yaitu: 1) menyampaikan tujuan dan kompetensi, 2) mendemonstrasikan pengetahuan, 3) membimbing pelatihan, 4) mengecek pemahaman dan memberi umpan balik, dan 5) pelatihan lanjutan dan penerapan (Kardi \& Nur, 2000). Penerapan model pembelajaran langsung dalam pembelajaran IPA di kelas kurang efektif dalam meningkatkan pemahaman konsep siswa. Model pembelajaran langsung berpusat pada guru, sehingga dalam proses pembelajaran lebih didominasi oleh guru. Penerapan model pembelajaran langsung tidak sepenuhnya memberikan pemahaman konsep yang kuat bagi siswa. Hal ini terjadi karena siswa tidak mendapatkan kesempatan mengeksplorasi pengetahuannya. Model pembelajaran langsung bergantung pada kemampuan siswa untuk mengasimilasikan informasi melalui kegiatan mendengarkan, mengamati, dan mecatat. Akibat dari pembelajaran tersebut siswa menjadi terbiasa menerima apa yang diberikan oleh guru tanpa berusaha menemukan sendiri konsepkonsep yang dipelajari. Kondisi ini berimplikasi pada kebiasaan siswa untuk menghafal setiap materi pelajaran yang berpengaruh pada rendahnya pemahaman konsep siswa.

Menurut pandangan konstruktivisme, belajar bukanlah penambahan informasi baru secara sederhana, tetapi melibatkan interaksi antara pengetahuan baru dan pengetahuan yang telah dimiliki sebelumnya
(Sadia, 2014). Pengetahuan yang telah dimiliki siswa sebelumnya disebut pengetahuan awal. Siswa menggunakan pengetahuan awal untuk menginterpretasi ide-ide yang dipelajari dan mengkaitkan ideide tersebut dengan apa yang telah diketahui dan diyakini sebelumnya (Suastra, 2009). Pengetahuan awal siswa dapat dijadikan untuk merancang model pembelajaran yang relevan dalam memfasilitasi proses pengkonstruksian pengetahuan oleh siswa secara optimal. Siswa yang memiliki pengetahuan awal tinggi akan mudah menerima dan mengikuti pelajaran. Sebaliknya siswa yang pengetahuan awalnya rendah cenderung menerima informasi baru sebagai beban yang harus di hafalkan, sehingga sulit menerima dan mengikuti pelajaran.

Banyak hal yang perlu diperhatikan guru untuk mengatasi masalah tersebut, salah satunya model pembelajaran yang diterapkan. Guru dapat memvariasikan dan memodifikasi model pembelajaran yang digunakan untuk memudahkan siswa dalam memahami suatu konsep (Mari \& Gumel, 2015). Upaya yang dapat dilakukan guru untuk mengatasi permasalahan tersebut adalah menerapkan model pembelajaran yang relevan dalam proses pembelajaran, sehingga dapat meningkatkan pemahaman konsep siswa. Model pembelajaran yang dimaksud adalah model pembelajaran kooperatif. Sanjaya (2016) menyatakan model pembelajaran kooperatif adalah rangkaian kegiatan belajar yang dilakukan siswa dalam kelompok-kelompok tertentu untuk mencapai tujuan pembelajaran yang telah dirumuskan. Pembelajaran secara berkelompok akan memudahkan siswa untuk memahami konsep-konsep yang sulit dan dapat meningkatkan kemampuan berpikir (Rusman, 2010). Salah satu model pembelajaran kooperatif yang dapat meningkatkan pemahaman konsep siswa adalah model pembelajaran kooperatif tipe Jigsaw. Isjoni (2009) menyatakan model pembelajaran kooperatif jigsaw merupakan salah satu tipe pembelajaran kooperatif yang mendorong siswa aktif dan saling membantu dalam menguasai materi pelajaran untuk mencapai prestasi yang maksimal.

Model pembelajaran kooperatif tipe Jigsaw mengkondisikan siswa untuk 
beraktivitas secara kooperatif dalam dua kelompok, yaitu kelompok asal dan kelompok ahli (Huda, 2011). Seluruh aktivitas tersebut melibatkan siswa secara aktif dalam proses pembelajaran sehingga proses pembelajaran menjadi lebih bermakna. Kebermaknaan tersebut dapat meningkatkan penguasaan kompetensi pengetahuan IPA siswa (Dwipayana et al., 2017). Secara umum kegiatan dalam model pembelajaran kooperatif tipe Jigsaw terdiri dari 4 langkah pembelajaran, yaitu: 1) pembagian tugas, 2) diskusi kelompok ahli, 3) diskusi kelompok asal, dan 4) integrasi dan evaluasi (Slavin, 2005).

Beberapa penelitian mengemukakan bahwa model pembelajaran kooperatif tipe Jigsaw memberikan dampak positif bagi pemahaman konsep siswa. Penelitian yang dilakukan oleh Dwipayana et al. (2017) menunjukkan bahwa siswa yang belajar dengan model pembelajaran kooperatif tipe Jigsaw memiliki penguasaan kompetensi pengetahuan IPA yang lebih tinggi dibandingkan dengan siswa yang belajar dengan model pembelajaran konvensional. Penelitian yang dilakukan oleh Dat (2016) menyatakan bahwa model pembelajaran koopertaif tipe Jigsaw dapat meningkatkan retensi pengetahuan siswa. Hasil penelitian Antara (2014) menunjukan bahwa siswa yang belajar dengan model pembelajaran kooperatif tipe Jigsaw memiliki pemahaman konsep dan sikap ilmiah yang lebih tinggi dibandingkan dengan siswa yang belajar dengan model pembelajaran konvensional.

Model pembelajaran kooperatif tipe Jigsaw memberikan kesempatan kepada siswa untuk membangun pengetahuannya secara individu maupun kooperatif. Siswa harus saling membelajarkan untuk mencapai hasil belajar yang baik. Lingkungan belajar yang demikian dapat membuat pemahaman siswa bertahan dalam jangka waktu yang panjang. Hal tersebut membuat siswa mudah memahami dan mengikuti proses pembelajaran, sehingga dapat meningkatkan pemahaman konsep siswa.

\section{METODE}

Penelitian ini termasuk penelitian eksperimen semu dengan rancangan Nonequivalent Pretest-Posttest Control Group Design. Populasi dalam penelitian ini adalah seluruh kelas VII SMP N 1 Sukasada pada semester genap tahun ajaran 2017/2018 yang berjumlah 236 siswa. Sampel penelitian dipilih dengan menggunakan teknik class random sampling. Sampel yang digunakan dalam penelitian berjumlah 59 siswa yang tersebar dalam 2 kelas, yaitu kelas eksperimen dan kelas kontrol.

Data utama dalam penelitian ini adalah pemahaman konsep siswa yang diperoleh dengan tes pemahaman konsep siswa. Tes pemahaman konsep yang digunakan berupa soal pilahan ganda diperluas. Penggunaan tes pilihan ganda diperluas menuntut siswa berpikir tentang alasan mengapa memilih jawaban benar (Santyasa dalam Wardani, 2013). Pada penelitian ini terdapat tiga variabel, yaitu variabel bebas, variabel terikat, dan variabel covariat. Variabel bebas pada penelitian ini adalah model pembelajaran. Model pembelajaran yang digunakan dalam penelitian ini yaitu model pembelajaran kooperatif tipe Jigsaw pada kelompok eksperimen dan model pembelajaran langsung pada kelompok kontrol. Variabel terikat pada penelitian ini adalah pemahaman konsep IPA siswa. Variabel covariat pada penelitian ini adalah pengetahuan awal siswa yang berfungsi sebagai kontrol statistik karena selain variabel bebas terdapat variabel lain yang dapat mempengaruhi variabel terikat.

Arikunto (2006) menyatakan bahwa semua jenis instrument sebelum digunakan perlu diyakinkan bahwa memang sudah baik sehingga apabila digunakan untuk mengumpulkan data akan menghasilkan data yang valid. Pengujian instrument meliputi: 1) pengujian validitas isi dan konstrak, 2) konsistensi internal butir tes, 3) indeks daya beda, 4) indeks kesukaran butir, dan 5) reliabilitas tes. Hasil pengujian instrument adalah tes pemahaman konsep IPA yang digunakan dalam penelitian. Tes pemahaman konsep IPA tersebut berjumlah 20 butir soal yang mewakili semua indikator dalam pembelajaran. Tes yang digunakan pada saat pretest dan posttest adalah tes yang sama.

Data yang diperoleh dianalisis secara deskriptif dan Anakova satu jalur. Metode analisis deskriptif digunakan untuk 
mendeskripsikan profil pemahaman konsep siswa yang dilihat berdasarkan distribusi frekuensi, nilai rata-rata, standar deviasi, gain score ternormalisasi, dan ketercapaian indikator pemahaman konsep dari hasil pretest dan posttest. Metode Anakova satu jalur digunakan untuk mengetahui hubungan antara kovariat, yaitu pengetahuan awal siswa dengan pemahaman konsep siswa. Sebelum dilakukan pengujian hipotesis dengan Anakova satu jalur terlebih dahulu data harus memenuhi beberapa asumsi yang meliputi: 1) Uji Normalitas sebaran data menggunakan Kolmogorov-Smirnov dengan bantuan SPSS 16.0 for windows. Kriteria pengujian yang digunakan adalah data berdistribusi normal apabila angka signifikansi yang dihasilkan lebih besar dari 0,05. 2) Uji Homogenitas mengguanakan Levene's Test of Wquality of Error Variance dengan bantuan SPSS 16.0 for windows. Kriteria pengujian yang digunakan adalah data memiliki varain yang sama, apabila angka signifikansi yang dihasilkan lebih besar dari 0,05. 3) Uji linieritas dengan melihat angka signifikansi pada linearity dan deviation from linearity berbantuan SPSS 16.0 for windows. Kriteria pengujian yang digunakan adalah data memiliki arah regresi yang signifikan dan berbentuk liniear apabila angka signifikansi pada linearity lebih kecil dari 0,05 dan angka signifikansi pada deviation from linearity lebih besar dari 0,05. Jika data hasil penelitian telah memenuhi persyaratan normalitas, homogenitas varian, dan linieritas maka Anakova satu jalur dapat dilanjutkan.

Pengujian hipotesis menggunakan uji $F$ melalui Anakova satu jalur bantuan SPSS 16.0 for windows. Kriteria pengujiannya adalah $\mathrm{H}_{0}$ ditolak jika nilai signifikansi lebih kecil dari 0,05 . Apabila hasil uji $F$ melalui Anakova satu jalur menunjukkan terdapat perbedaan antara rata-rata kelompok, maka diperlukan uji lanjut untuk menentukan seberapa besar derajat perbedaannya. Uji lanjut dalam penelitian ini menggunakan Least Significant Diference (LSD). Kriteria yang digunakan dalam penelitian adalah $\mathrm{H}_{0}$ ditolak jika harga mutlak $\left|\mu_{1}-\mu_{2}\right|>$ LSD.

\section{HASIL DAN PEMBAHASAN}

Profil pemahaman konsep IPA siswa dilihat berdasarkan nilai pretest dan posttest.
Pada kelas eksperimen yang menerapkan model pembelajaran kooperatif tipe Jigsaw diperoleh nilai pengetahuan awal siswa/ pretest siswa berkisar antara 32,50 sampai 60,00 dan nilai pemahaman konsep IPA siswa/posttest berkisar antara 56,25 sampai 82,50 . Pada kelas kontrol yang menerapkan model pembelajaran langsung diperoleh nilai pengetahuan awal siswa/pretest berkisar 31,25 sampai 60,00 dan nilai pemahaman konsep IPA siswa/posttest berkisar antara 42,50 sampai 77,50. Profil distribusi frekuensi nilai pretest dan posttest pada kelas eksperimen yang belajar dengan model pembelajaran kooperatif tipe Jigsaw dan kelas kontrol yang belajar dengan model pembelajaran langsung disajikan secara berturut-turut dalam grafik seperti Gambar 1 dan Gambar 2

Gambar 1

\section{Grafik Batang Distribusi Frekuensi Nilai} Pretest

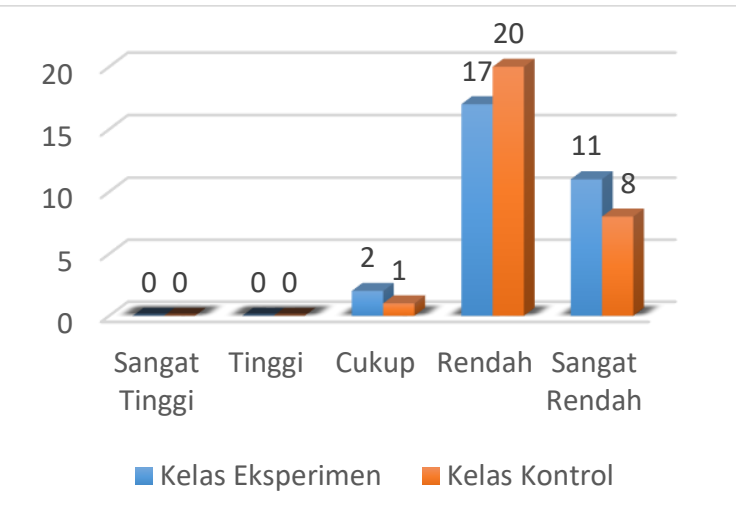

Gambar 2

Grafik Batang Distribusi Frekuensi Nilai Posttest

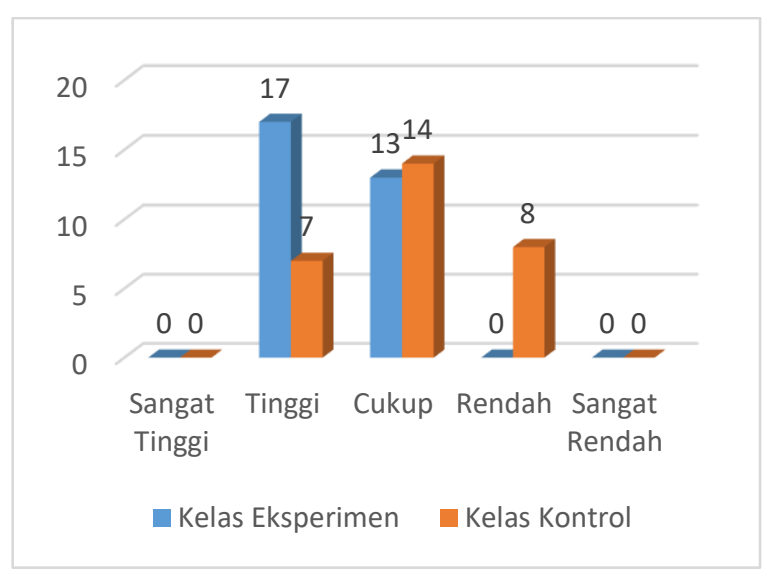


Nilai pretest dan posttest tersebut dianalisis secara deskriptif untuk mengetahui nilai rata-rata, standar deviasi, dan $\mathrm{N}$-gain, kemudian disajikan pada Tabel 2.

Tabel 2. Profil Nilai Pretest dan Posttest

\begin{tabular}{lcrlll}
\hline & \multicolumn{2}{c}{ Kelas Eksperimen } & \multicolumn{2}{c}{ Kelas Kontrol } \\
& Pre & Post & Pre & Post \\
\hline Rata-rata & 44,21 & 71,97 & 44,18 & 60,94 \\
Sd & 7,61 & 7,05 & 6,07 & 10,06 \\
$\langle\mathrm{~g}\rangle$ & & 0,74 & & & 0,52 \\
\hline
\end{tabular}

Tabel 2 menunjukkan bahwa siswa pada kelas eksperimen yang belajar dengan model pembelajaran kooperatif tipe Jigsaw mengalami peningkatan pemahaman konsep IPA yang lebih tinggi dibandingkan dengan kelas kontrol yang belajar dengan model pembelajaran langsung. Peningkatan nilai pemahaman konsep IPA pada penelitian ini sesuai dengan hasil penelitian Dat (2016) yang menunjukkan bahwa model pembelajaran kooperatif tipe Jigsaw dapat meningkatkan retensi pengetahuan siswa. Retensi pengetahuan merupakan kemampuan siswa untuk mengingat pengetahuan yang nantinya akan berdampak pada pemahaman konsep siswa.

Sebagai tindak lanjut dari hasil pretest dan posttest yang diperoleh, maka dilakukan analisis deskripsi terhadap jawaban siswa pada setiap indikator pemahaman konsep. Tujuannya adalah untuk mengetahui ketercapaian indikator pemahaman konsep. Skor yang diperoleh pada setiap indikator kemudian dianalisis menggunakan gain score ternormalisasi dan disajikan pada Tabel 3.

Tabel 3. Profil Pemahaman Konsep IPA

\begin{tabular}{lcc}
\hline $\begin{array}{c}\text { Indikator Pemahaman } \\
\text { Konsep }\end{array}$ & Kelas Eksperimen & Kelas Kontrol \\
\hline 1. Menafsirkan & 0,87 & 0,33 \\
2. Mencontohkan & 0,80 & 0,38 \\
3. Mengklasifikasikan & 0,62 & 0,43 \\
4. Merangkum & 0,83 & 0,47 \\
5. Menyimpulkan & 0,79 & 0,61 \\
6. Membanding kan & 0,55 & 0,29 \\
7. Menjelaskan & 1,00 & 0,72 \\
\hline
\end{tabular}

Tabel 3 menunjukkan bahwa siswa pada kelas eksperimen yang belajar dengan model pembelajaran kooperatif tipe Jigsaw mengalami peningkatan ketercapaian pada setiap indikator pemahaman konsep yang lebih tinggi dibandingkan dengan siswa pada kelas kontrol yang belajar dengan model pembelajaran langsung. Hal ini sesuai dengan hasil penelitian Dwipayana et al. (2017) menunjukkan bahwa siswa yang belajar dengan model pembelajaran kooperatif tipe Jigsaw memiliki penguasaan kompetensi pengetahuan IPA yang lebih tinggi dibandingkan dengan siswa yang belajar dengan model pembelajaran konvensional. Model pembelajaran kooperatif tipe Jigsaw mampu memfasilitasi siswa dalam mengkontruksi pengetahuannya. Setiap siswa diberikan tanggung jawab individu pada suatu topik di kelompok ahli agar nantinya dapat menjelaskannya kepada siswa lainnya di kelompok asal. Proses pembelajaran tersebut menciptakan ketergantungan positif antar siswa sehingga dapat memfasilitasi siswa dalam meningkatkan pemahaman konsep. Disisi lain, model pembelajaran langsung menjadikan guru sebagai satusatunya sumber informasi dan tidak memberikan kesempatan kepada siswa untuk berperan aktif dalam proses 
pembelajaran sehingga tidak terjadi proses pembelajaran yang bermakna.

Hasil uji asumsi menujukkan bahwa data penelitian berdistribusi normal $(p>$ $0,05)$, homogen $(p>0,05)$, memiliki arah regresi yang berarti dan berbentuk linier $(p$ linearity < 0,05; $p$ deviation from linearity > $0,05)$ Berdasarkan hasil uji asumsi yang sudah dilakukan dapat disimpulkan bahwa data hasil penelitian telah memenuhi persyaratan sehingga uji hipotesis dengan Anakova satu jalur dapat dilanjutkan. Hipotesis yang akan diuji dalam penelitian ini adalah sebagai berikut.

1. $H_{0}: \mu_{1}=\mu_{2}$ (Tidak terdapat perbedaan pemahaman konsep IPA antara siswa yang belajar dengan model pembelajaran kooperatif tipe Jigsaw dan model pembelajaran langsung).

2. $H_{a}: \mu_{1} \neq \mu_{2}$ (Terdapat perbedaan pemahaman konsep IPA antara siswa yang belajar dengan model pembelajaran kooperatif tipe Jigsaw dan model pembelajaran langsung).

Hasil uji Anakova satu jalur menunjukkan bahwa: (1) Pengaruh pengetahuan awal siswa/hasil pretest terhadap pemahaman konsep IPA siswa/hasil posttest menunjukkan nilai statistik $F$ sebesar 9,006 dengan $p<0,05$. $\mathrm{Hal}$ ini menunjukkan bahwa terdapat pengaruh yang signifikan kovariat, yaitu pengetahuan awal siswa terhadap pemahaman konsep. (2) Setelah pengaruh kovariat, yaitu pengetahuan awal siswa dikendalikan secara statistik, pengaruh model pembelajaran terhadap pemahaman konsep IPA siswa menunjukkan nilai statistik $F$ sebesar 18,063 dengan $p<0,05$ sehingga keputusan yang dapat diambil adalah $\mathrm{H}_{0}$ ditolak. Hal ini berarti bahwa terdapat perbedaan pemahaman konsep IPA antara siswa yang belajar dengan model pembelajaran kooperatif tipe Jigsaw dan model pembalajaran langsung. (3) Nilai $R$ squared yang didapat berdasarkan hasil Anakova satu jalur menunjukkan bahwa besarnya kontribusi model pembelajaran terhadap perbedaan peningkatan pemahaman konsep IPA siswa pada kelas eksperimen yang belajar dengan model pembelajaran kooperatif tipe Jigsaw dan kelas kontrol yang belajar dengan model pembelajaran langsung adalah sebesar 0,302 .

Sebagai tindak lanjut dari pengujian hipotesis dilakukan uji lanjut, yaitu analisis signifikansi perbedaan skor rata-rata pemahaman konsep IPA siswa antara siswa yang belajar dengan model pembelajaran kooperatif tipe Jigsaw dan model pembelajaran langsung menggunakan uji Least Significant Diference (LSD). Nilai LSD yang diperoleh sebesar 10,54 dan perbedaan skor rata-rata pemahaman konsep IPA antara kelas eksperimen yang belajar dengan model pembelajaran kooperatif tipe Jigsaw dan kelas kontrol yang belajar dengan model pembelajaran langsung adalah $\Delta \mu=\left|\mu_{1}-\mu_{2}\right|=22,585$. Nilai $\left|\mu_{1}-\mu_{2}\right|>$ LSD sehingga dapat disimpulkan bahwa, siswa yang belajar dengan model pembelajaran kooperatif tipe Jigsaw memiliki pemahaman konsep yang lebih tinggi dibandingkan dengan siswa yang belajar dengan siswa yang belajar dengan model pembelajaran langsung.

Perbedaan paradigma pembelajaran menjadi esensi fundamental dari masingmasing model pembelajaran yang digunakan. Perbedaan paradigma pembelajaran yang dimaksud adalah pendekatan konstruktivisme pembelajaran dan pendekatan behaviorisme pembelajaran. Santyasa (2007) menyatakan bahwa pandangan konstruktivisme dalam pembelajaran lebih mengutamakan penyelesaian masalah dan mengembangkan konsep ketimbang menghafal prosedur dan menggunakannya untuk memperoleh satu jawaban benar. Model pembelajaran kooperatif tipe Jigsaw merupakan salah satu model pembelajaran yang berlandaskan paradigma kontruktivisme.

Berdasarkan data hasil posttest, pemahaman konsep IPA siswa pada kelas eksperimen mengalami peningkatan dengan nilai $\mathrm{N}$-gain sebesar 0,74 setelah diberikan perlakuan menggunakan model pembelajaran kooperatif tipe Jigsaw. Ketercapaian setiap indikator pemahaman konsep juga mengalami peningkatan. Sintaks dalam model pembelajaran kooperatif tipe Jigsaw mengajarkan siswa untuk memiliki rasa tanggung jawab secara mandiri, menciptakan ketergantungan positif, 
dan terjadi suatu pembelajaran yang bermakna.

Tahapan diskusi kelompok ahli memberikan kesempatan pada siswa untuk berdiskusi dan saling membantu dalam memahami sub materi tersebut. Belajar dengan teman sebaya memudahkan siswa untuk memahami materi pelajaran. Tahap ini membuat siswa terbiasa untuk menafsirkan sub materi yang menjadi tanggungjawab mereka, kemudian mengklasifikan dan memberikan contohnya. Hal ini akan mempermudah siswa dalam menjelaskan sub materi tersebut ketika kembali ke kelompok asal. Tahapan ini berdampak pada ketercapaian indikator pemahaman konsep, khusunya indikator menafsirkan, mencontohkan, dan mengklasifikasi yang mengalami peningkatan secara berturut-turut sebesar 0,87; 0,80;0,62. Ketika kembali ke kelompok asal setiap siswa akan menjelaskan secara bergilir sub materi yang menjadi tanggungjawabnya masing-masing. Setiap siswa akan memahami materi pelajaran dengan baik, minimal memahami sub materi yang mereka diskusikan pada kelompok ahli, sehingga berdampak pada peningkatan pemahaman konsep, khususnya pada indikator menjelaskan. Indikator menjelaskan mengalami peningkatan yang paling tinggi dengan nilai $\mathrm{N}$-gain sebesar 1,00.

Model pembelajaran kooperatif tipe Jigsaw juga memfasilitasi siswa untuk merangkum atau menyimpulkan materi pelajaran, sehingga memudahkan siswa untuk memahami materi pelajaran. Hal tersebut berdampak pada ketercapaian indikator pemahaman konsep, yaitu pada indikator merangkumkan dan menyimpulkan. Berdasarkan hasil N-gain, indikator merangkumkan dan menyimpulkan secara berturut-turut mengalami peningkatan sebesar 0,83 dan 0,79. Indikator membandingkan mengalami peningkatan yang paling rendah dengan nilai $\mathrm{N}$-gain sebesar 0,55. Hal ini disebabkan karena pada tahapan diskusi kelompok asal, siswa memiliki kendala dalam membandingkan masing-masing penjelasan sub materi yang disampaikan oleh siswa lainnya. Namun, peningkatan ketercapaian indikator membandingkan masih berada pada kualifikasi sedang.
Pada model pembelajaran kooperatif tipe Jigsaw siswa aktif berdiskusi dalam kelompok asal dan kelompok ahli, sehingga memudahkan siswa dalam memahami materi pelajaran. Hal ini sesuai dengan pendapat Trisianawati et al. (2016) yang menyatakan bahwa siswa terlibat aktif dalam penerapan model pembelajaran kooperatif tipe Jigsaw. Antara (2014) yang menyatakan bahwa melalui pemberian permasalahan dan tanggung jawab untuk memecahkannya serta menjelaskannya kepada siswa lainnya, setiap siswa akan terdorong untuk belajar lebih mendalam sehingga penguasaan konsep materi pelajaran menjadi lebih baik. Model pembelajaran kooperatif tipe Jigsaw memberikan kesempatan kepada siswa untuk membangun pengetahuannya secara individu maupun kooperatif, sehingga dapat meningkatkan daya ingat siswa terhadap materi pelajaran karena pengetahuan berasal dari hasil konstruksi pemikiran siswa sendiri (Setyowati et al., 2015).

Disisi lain, pandangan behaviorisme memandang siswa sebagai komponen pasif dalam pembelajaran yang memerlukan motivasi luar dan dipengaruhi oleh penguatan/reinforcement yang diberikan oleh guru. Model pembelajaran langsung merupakan salah satu model pembelajaran yang berlandaskan paradigma behaviorisme. Berdasarkan data hasil posttest, pemahaman konsep IPA siswa pada kelas kontrol mengalami peningkatan dengan nilai $\mathrm{N}$-gain sebesar 0,52 setelah diberikan perlakuan menggunakan model pembelajaran langsung.

Proses pembelajaran pada model pembelajaran langsung cenderung hanya menghantarkan siswa untu mencapai tujuan kurikulum, sehingga proses pembelajaran dikelas memiliki ciri-ciri sebagai berikut: (1) guru aktif sedangkan siswa pasif,(2) pembelajaran masih berpusat pada guru, dan (3) pengetahuan ditransfer dari guru ke siswa. Hal ini sesuai dengan pendapat Trisianawati et al. (2016) yang menyatakan bahwa selama proses pembelajaran berlangsung tidak semua siswa terlibat aktif karena pembelajaran hanya berupa interaksi melalui penuturan lisan dari guru kepada siswa. Akibatnya, siswa menjadi terbiasa menerima apa yang diberikan oleh guru 
tanpa mau berusaha dan mengembakan potensi yang dimiliki. Kondisi ini berdampak pada kurangnya motivasi dan minat siswa terhadap materi pelajaran yang bermuara pada rendahnya pemahaman konsep siswa. Hal ini sejalan dengan data hasil penelitian yang menunjukkan bahwa siswa yang belajar dengan model pembelajaran langsung mengalami peningkatan ketercapaian indikator pemahaman konsep yang lebih rendah dibandingkan dengan model pembelajaran kooperartif tipe Jigsaw.

Jadi secara keseluruhan dapat disimpulkan bahwa model pembelajaran kooperatif tipe Jigsaw mampu mengembangkan pemahaman konsep IPA siswa yang lebih baik dibandingkan dengan model pembelajaran langsung. Dat (2016) menyatakan bahwa model pembelajaran kooperatif tipe Jigsaw memberikan suasana belajar yang menyenangkan sehingga siswa dapat secara aktif bekerjasama dengan sesama siswa dalam setiap kelompok. Suasana belajar yang demikian membuat siswa mudah menggali informasi dan meningkatkan kemampuan berkomunikasi sehingga dapat meningkatkan retensi pengetahuan siswa yang nantinya bermuara pada peningkatan pemahaman konsep. Hal tersebutlah yang menjadi indikasi bahwa secara empiris dan teoritis siswa yang belajar dengan model pembelajaran kooperatif tipe Jigsaw memiliki pemahaman konsep yang lebih baik dibandingkan dengan siswa yang belajar dengan model pembelajaran langsung.

Hasil penelitian ini sejalan dengan hasil-hasil penelitian sebelumnya yang relevan dengan penelitian ini. Hasil penelitian Trisianawati et al. (2016) menunjukkan bahwa penerapan model pembelajaran kooperatif tipe Jigsaw memberikan pengaruh yang signifikan terhadap hasil belajar siswa serta dapat melatih siswa dalam beragumentasi antara sesama teman di dalam kelas. Penelitian yang dilakukan oleh Antara (2014) juga menunjukan bahwa model pembelajaran kooperatif tipe Jigsaw berpengaruh positif terhadap kemampuan pemahaman konsep siswa. Siswa yang belajar dengan model pembelajaran kooperatif tipe Jigsaw memiliki pemahaman konsep lebih tinggi daripada yang mengikuti pembelajaran konvensional.
Temuan-temuan pada penelitian tersebut menujukkan bahwa model pembelajaran kooperatif tipe Jigsaw efektif dalam meningkatkan pemahaman konsep siswa.

\section{SIMPULAN DAN SARAN}

Berdasarkan hasil penelitian dan pembahasan, dapat disimpulkan bahwa: pertama, pemahaman konsep IPA siswa yang belajar dengan model pembelajaran kooperatif tipe Jigsaw berkualifikasi tinggi $(\mathrm{N}$-gain=0,74). Ketercapaian indikator menafsirkan, mencontohkan, merangkum, menyimpulkan, dan menjelaskan berkualifikasi tinggi. Ketercapaian indikator mengklasifikasikan dan membandingkan berkualifikasi sedang. Kedua terdapat perbedaan pemahaman konsep IPA antara siswa yang belajar dengan model pembelajaran kooperatif tipe Jigsaw dan model pembelajaran langsung $(F=18,063, p$ $<0,05)$. Siswa yang belajar dengan model pembelajaran kooperatif tipe Jigsaw secara signifikan memiliki pemahaman konsep IPA yang lebih tinggi dibandingkan dengan model pembelajaran langsung $\left(\left|\mu_{1}-\mu_{2}\right|>\right.$ LSD).

Berdasarkan simpulan tersebut, saran yang dapat diajukan adalah sebagai berikut.

1. Model pembelajaran kooperatif tipe Jigsaw dapat dijadikan solusi untuk meningkatan pemahaman konsep siswa. Tahapan diskusi kelompok ahli berpengaruh pada peningkatan indikator menafsirkan dan mencontohkan dengan kualifikasi tinggi. Tahapan diskusi kelompok asal berpengaruh pada peningkatan indikator menjelaskan dengan kualifikasi tinggi. Tahapan integrasi dan evaluasi berpengaruh pada peningkatan indikator merangkum dan menyimpulkan.

2. Bagi guru/peneliti lainnya yang akan menerapkan model pembelajaran kooperatif tipe Jigsaw agar memfasilitasi siswa pada saat diskusi kelompok ahli dengan memberikan suatu contoh analogi yang berkaitan dengan mengklasifikasi, sehingga siswa paham tentang makna mengklasifikasi. Peneliti juga menyarankan pada tahapan diskusi kelompok asal agar selalu mengecek 
perkembangan diskusi setiap kelompok dan membantu jalannya diskusi dengan menginstruksikan siswa mencari perbedaan dan persamaan dari sub materi yang disampaikan oleh masing-masing anggota kelompok lainnya, sehingga siswa paham tentang makna membandingkan.

3. Bagi peneliti lainnya agar melaksanakan penelitian sejenis dengan pemilihan materi yang berbeda untuk mendapatkan gambaran yang lebih meyakinkan mengenai pemahaman konsep IPA.

\section{DAFTAR PUSTAKA}

Anderson, L.W., \& Krahtwohl, D.R. 2015. Kerangka Landasan Utama Pembelajaran, Pengajaran, dan Asesmen. Yogyakarta: Pustaka Belajar.

Antara, I.P.P.A. 2014. Pengaruh Pembelajaran Kooperatif Jigsaw Terhadap Penguasaan Konsep Kimia dan Sikap Ilmiah Siswa. e-Jurnal Pendidikan dan Pengajaran, 47(1), 7684.

Arends. R.I. 2013. Belajar untuk Mengajar. Terjemahan Learning to Teach. Edisi 9. Jakarta: Salemba Humanika.

Arikunto, S. 2006. Prosedur Penelitian Suatu Pendekatan Praktik. Jakarta: Rineka Cipta.

Dat, T.V. 2016. The Effects of Jigsaw Learning on Students' Knowledge Retention in Vietnamese Higher Education. International Journal of Higher Education, 5(2), 236-251. ISSN 1927-6044. E-ISSN 1927-6052.

Dwipayana, I.M., Manuaba, I.B.S., \& Wiyasa, I.K.N. 2017. Pengaruh Model Pembelajaran Kooperatif Tipe Jigsaw Terhadap Penguasaan Kompetensi Pengetahuan IPA Siswa Kelas V SD Gugus Kapten Kompyang Sujan Denpasar Barat Tahun Ajaran 2016/2017. e-Journal PGSD Universitas Pendidikan Ganesha, 5(3).
Iswadi, H. Sekelumit dari Hasil PISA 2015 yang baru dirilis. Artikel. 7 Desember 2016. Diakses pada tanggal 28 November 2017, dari:http://www.ubaya.ac.id/2014/content /articles_detail/230/Sekelumit-Dari-HasilPISA-2015-Yang-Baru-Dirilis.html.

Huda, M. 2011. Cooperative Learning: Metode Teknik, Struktur, dan Model Penerapan. Yogyakarta: Pustaka Belajar.

Isjoni. 2009. Pembelajaran Kooperatif: Meningkatkan Kecerdasan Komunikasi Antar Peserta Didik. Yogyakarta: Pustaka Pelajar.

Kardi, S., \& Nur. M. 2000. Pengajaran Langsung. Surabaya: UNESA-University Press.

Kesnajaya, I.K., Dantes, N., \& Dantes, G.R. 2015. Pengaruh Model Pembelajaran Kooperatif Tipe Jigsaw Terhadap Motivasi Belajar dan Hasil Belajar IPA Siswa Kelas V Pada SD Negeri 3 Tianyar Barat. e-Jurnal Program Pascasarjana Universitas Pendidikan Ganesha, 5.

Mari, J.S \& Gumel, S.A. 2015. Effects of Jigsaw Model of Cooperative Learning on Self-Efficacy and Achievement in Chemistry among Concrete and Formal Reasoners in Colleges of Education in Nigeria. International Journal of Information and Education Technology, 5(3), 196-199.

Nilai UN SMP/MTs Se-Bali Turun. Artikel. 2 Juni 2017. Diakses pada tanggal 28 November

2017, dari:http://baliportalnews.com/2017 /06/nilai-un-smpmts-se-bali-turun/.

Oviyana, I.W., Wirya, I.N., \& Sudarma, I.K. 2015. Pengaruh Model Pembelajaran Kooperatif Tipe Jigsaw II Terhadap Hasil Belajar IPA Siswa Kelas VI SD. e-Jurnal PGSD Universitas Pendidikan Ganesha, 3(1). 
Prastika, I.A.D. 2014. Pengaruh Model Pembelajaran Kooperatif Tipe STAD (Student Teams Achievement Division) Terhadap Pemahaman Konsep IPA Siswa Kelas VIII SMP Negeri 6 Singaraja Tahun Pelajaran 2013/2014. Skripsi (tidak diterbutkan). Jurusan Pendidikan Fisika, FMIPA. Universitas Pendidikan Ganesha.

Rusman. 2010. Model-Model Pembelajaran: Mengembangkan Profesionalisme Guru. Jakarta: PT Raja Grafindo Persada.

Sadia, I.W. 2014. Model-Model Pembelajaran Sains Konstruktivistik. Singaraja: Graha Ilmu.

Sanjaya, W. 2016. Strategi Pembelajaran Berorientasi Standar Proses Pendidikan. Jakarta: Kencana.

Santyasa, I.W. 2007. Model-model Pembelajaran Inovatif. Makalah. Disajikan dalam pelatihan tentang penelitian tindakan kelas bagi guru-guru SMP dan SMA di Nusa Penida, tanggal 29 Juni-1 Juli 2007. Diakses pada tanggal 24 November 2017,dari: www.freewebs.com.

Sarnapi. Peringkat Pendidikan Indonesia Masih Rendah. Artikel. 18 Juni 2016. Diakses pada tanggal 28 November 2017, dari http: //www.pikiranrakyat.com/pendidikan/2016/06/18/perin gkat-pendidikan-indonesia-masihrendah-372187.

Setyowati, B.E., Widiyatmiko, A., \& Sarwi. 2015. Efektivitas Model Pembelajaran Kooperatif Jigsaw II Berbantuan LKS untuk Meningkatkan Pemahaman Konsep dan Karakter Siswa. Unnes Science Education Journal, 4(3), 982989. ISSN 2252-6617.

Slavin, R.E. 2005. Cooperative Learning: Teori, Riset, dan Praktik. Terjemahan Cooperative Learning: theory, research, and practice. 1995. Cetakan ke-2. Bandung: Nusa Media.
Suastra, I.W. 2009. Pembelajran Sains Terkini. Singaraja: Undiksha.

Surayya, L., Subagia, I.W., \& Tika, I.N. 2014. Pengaruh Model Pembelajaran Think Pair Share terhadao Hasil Belajar IPA Ditinjau dari Keterampilan Berpikir Kritis Siswa. e-Journal Program Pascasarjana Universitas Pendidikan Ganesha, 4.

Trisianawati, E., Djudin, T. \& Setiawan, R. 2016. Pengaruh Model Pembelajaran Kooperatif Tipe Jigsaw Terhadap Hasil Belajar Siswa pada Materi Vektor di Kelas X SMA Negeri 1 Sanggau Ledo. Jurnal Penelitian Fisika dan Aplikasinya (JPFA), 6(2), 51-60. ISSN 2087-9946. EISSN 2477-1775.

Wardani, K.S.K. 2013 Pengaruh Model Pembelajaran Kooperatif Tipe Jigsaw II Bermuatan Content Local Genius Terhadap Pemahaman Konsep Sains Siswa Kelas VIII di SMP Negeri 4 Singaraja Tahun Pelajaran 2012/2013. Skripsi (tidak diterbutkan). Jurusan Pendidikan Fisika, FMIPA. Universitas Pendidikan Ganesha.

Widiadnyana, W., I.W. Sadia, \& I.W. Suastra. 2014. Pengaruh Model Discovery Learning Terhadap Pemahaman Konsep IPA dan Sikap Ilmiah Siswa SMP. eJournal Program Pascasarjana Universitas Pendidikan Ganesha, 4.

Widiawati, N.P., Pudjawan, K., \& Margunayasa, I.G. 2015. Analisis Pemahaman Konsep Dalam Pelajaran IPA pada Siswa Kelas IV SD di Gugus II Kecamatan Banjar. e-Journal PGSD Universitas Pendidikan Ganesha, 3(1). 